\title{
INFECTOBESITY DAN PERIODONTITIS: HUBUNGAN DUA ARAH OBESITAS DAN PENYAKIT PERIODONTAL
}

\author{
I Komang Evan Wijaksana*
}

\begin{tabular}{c}
\hline Keywords: \\
Periodontal disease, \\
Periodontitis, Obesity, \\
Infectobesity \\
\hline
\end{tabular}

\section{ABSTRACT}

Background: Obesity and periodontal diseases are two highly prevalent chronic conditions in Indonesia. Both obesity and periodontitis have been recognized as a major risk factor for a number of systemic diseases. Obesity related to the etiology and progression of periodontal disease was well known, but a recent study describes the role of periodontitis to obesity.

Purpose: The aim of this article to explain possible bidirectional relationship of periodontitis and obesity, so that dental practitioners may play an important role in management both obesity and periodontal disease.

Literature review: The concept of infectobesity refers to obesity of infectious origin was accepted for the possible role of oral bacteria in the development of obesity. Excessive storage of adipose tissue in obese individuals leads to the release of adipokines which produce inflammatory. Relentless release of pro-inflammatory cytokines into the systemic circulation from adipose tissue in obese individuals and periodontal bacteria and its product provides a systemic inflammatory overload and may be a reservoir for bidirectional relationship of periodontitis and obesity. Maintaining good oral health is also fundamental for obese individuals. Dental practitioners should play important role in managements by educate their obese patients and refer the patient to physician and dietitian for a proper maintaining obesity.

Conclusion: There is a bidirectional relationship between obesity ang periodontal disease.

\section{PENDAHULUAN}

Obesitas dan penyakit periodontal merupakan dua kondisi yang bersifat kronis dan prevalensinya cenderung meningkat pada penduduk Indonesia. Obesitas adalah masalah gizi berupa kelebihan berat badan sebagai akibat dari penimbunan lemak tubuh yang berlebihan. Data Riset Kesehatan Dasar (RISKESDAS) 2013 Departemen Kesehatan Republik Indonesia menunjukkan 15,4 persen penduduk dewasa (>18 tahun) mengalami obesitas menurut indeks masa tubuh (IMT $\geq 27,0$ ). Angka tersebut meningkat dari tahun $2007(10,3 \%)$ dan tahun $2010(11,7 \%){ }^{1}$.
Penyakit periodontal merupakan masalah kesehatan gigi dan mulut yang sering dialami masyarakat Indonesia dengan prevalensi 96,58 persen pada semua kelompok umur ${ }^{2}$.

Periodontitis merupakan penyakit periodontal berupa inflamasi kronis pada jaringan penyangga gigi yang disebabkan oleh bakteri. Proses kerusakan jaringan periodontal pada periodontitis diawali akumulasi plak yang mengandung bakteri dan toksin yang bersifat patogenik. Interaksi antara bakteri plak dan produknya serta respon tubuh sel penjamu memicu respon inflamasi yang dapat menyebabkan ulserasi pada gingiva, kerusakan jaringan ikat, kehilangan tulang

\footnotetext{
* Dokter gigi, Singaraja-Bali

Korespondensi: drg.evanwijaksana@gmail.com
} 
alveolar hingga kehilangan gigi ${ }^{3}$.

Obesitas dan periodontitis diyakini berperan erat dalam timbulnya berbagai penyakit sistemik seperti diabetes mellitus, penyakit kardiovaskular, penyakit pernafasan, dan gangguan kehamilan. Berbagai penelitian turut membuktikan bahwa obesitas juga berperan dalam timbulnya periodontitis. Hubungan antara obesitas dan periodontitis pertama kali dilaporkan oleh Perlstein dan Bissada pada tahun 1977 ketika mengamati perubahan patologi pada tikus obesitas yang mengalami periodontitis ${ }^{4}$.

Penelitian terhadap peran obesitas sebagai faktor resiko periodontitis sudah cukup banyak diteliti. Dalam beberapa tahun terakhir beberapa peneliti turut meneliti peranan periodontitis sebagai faktor resiko obesitas. Konsep Infectobesity yang diperkenalkan oleh Dr Nikhil membuka kemungkinan peran bakteri periodontal dalam menyebabkan obesitas. Infectobesity merupakan obesitas yang dipicu oleh adanya agen infeksius ${ }^{5}$. Socransky dan Haffajee memperkirakan sekitar 1 gram (1011) bakteri tertelan dalam $500-1500 \mathrm{~mL}$ saliva setiap harinya. Tingginya jumlah dan jenis bakteri yang terdapat rongga mulut memiliki potensi untuk mempengaruhi secara langsung sistem pencernaan manusia yang mengarah pada obesitas ${ }^{6}$.

Artikel ini bertujuan untuk mengungkapkan interaksi dua arah antara obesitas dan periodontitis, sehingga dokter gigi dalam melaksanakan tugas sebagai paramedis dapat terlibat aktif secara langsung untukmenurunkan prevalensi penyakit periodontal yang diinduksi obesitas serta dapat secara tidak langsung menurunkan prevalensi obesitas melalui terapi periodontal dan instruksi peningkatan kebersihan rongga mulut serta komunikasi, informasi dan edukasi tentang akibat obesitas kepada pasiennya.

\section{Obesitas: Definisi dan Pedoman Evaluasi}

Obesitas adalah masalah gizi berupa kelebihan berat badan sebagai akibat dari penimbunan lemak tubuh yang berlebihan. Obesitas disebabkan oleh ketidakseimbangan antara jumlah energi yang masuk dengan yang dibutuhkan oleh tubuh untuk berbagai fungsi biologis seperti pertumbuhan fisik, perkembangan, aktivitas, pemeliharaan kesehatan ${ }^{7}$.

Evaluasi terhadap obesitas dapat dilakukan melalui beberapa metode standar yakni indeks masa tubuh (IMT), lingkar pinggang (LP), rasio lingkar pinggang dan pinggul serta persentase lemak ${ }^{3,8}$. IMT merupakan suatu pengukuran yang membandingkan berat badan dengan tinggi badan. Menurut WHO, individu mengalami obesitas jika nilai IMT $>30 \mathrm{~kg} / \mathrm{m}^{2}$ ${ }^{3}$. Mengingat bahwa ukuran badan orang asia yang lebih kecil dibanding ras lain, maka WHO memberikan nilai indeks baru bahwa orang asia dinyatakan obesitas jika nilai IMT $>23 \mathrm{~kg} /$ $\mathrm{m}^{2}$. RISKESDAS 2013 menggunakan kriteria tersendiri dalam menentukan obesitas melalui indeks masa tubuh yaitu IMT> $27 \mathrm{~kg} / \mathrm{m}^{2}{ }^{1}$.

Nilai lingkar pinggang yang digunakan dalam standar $\mathrm{WHO}$ adalah $88 \mathrm{~cm}$ untuk perempuan dan $102 \mathrm{~cm}$ untuk laki-laki. Nilai lingkar pinggang melebihi angka tersebut dinilai sebagai obesitas. Rasio antara lingkar pinggang dan pinggul diukur pada bagian teratas tulang pinggul dibagi dengan lingkar terlebar pada pinggul. Nilai standar untuk menyatakan obesitas jika rasio lingkar pinggang dan pinggul $>0,83$ untuk laki-laki 
dan 0,9 untuk wanita. Sedangkan obesitas berdasarkan persentase lemak jika nilainya $>25$ persen ${ }^{3}$.

Obesitas sebagai faktor resiko Periodontitis

Hubungan antara obesitas dan periodontitis pertama kali dilaporkan oleh Perlstein dan Bissada pada tahun 1977 ketika mengamati perubahan patologi pada tikus obesitas yang mengalami periodontitis. Hasil penelitian ini menunjukkan bahwa terjadi keradangan periodontal dan resorpsi tulang alveolar yang lebih parah pada tikus yang mengalami obesitas dibanding tikus dengan berat badan normal ${ }^{4}$.

Hubungan antara obesitas dan periodontitis pada manusia pertama kali dilaporkan Saito dan kolega pada tahun 1998. Hasil penelitiannya menunjukkan bahwa individu obesitas (IMT $\geq 30 \mathrm{~kg} / \mathrm{m}^{2}$ ) memiliki resiko relatif mengalami periodontitis 8.6 , angka ini 2.5 kali lebih tinggi dibanding resiko relatif periodontitis individu dengan berat badan normal tinggi (IMT 25$29,9 \mathrm{~kg} / \mathrm{m}^{2}$ ) sebesar 3.4. Setiap kenaikan 5 persen lemak tubuh, maka akan meningkatkan resiko relatif mengalami periodontitis sebesar 30 persen ${ }^{4}$. Genco dan kolega menunjukkan korelasi positif antara IMT dan keparahan kehilangan perlekatan periodontal. Dari 13.665 individu yang diteliti, memiliki satu atau lebih kehilangan perlekatan $\geq 3 \mathrm{~mm}$ dan kedalaman probing $\geq 4 \mathrm{~mm}^{9}$.

Penelitian hubungan obesitas terhadap periodontitis berdasarkan jenis kelamin telah dilakukan oleh Amin pada tahun 2008. Penelitian ini menunjukkan wanita dengan IMT normal mengalami kehilangan perlekatan 0,2 $\mathrm{mm}$, sedangkan wanita obesitas $2,1 \mathrm{~mm}$. Data ini menunjukkan wanita obesitas mengalami kehilangan perlekatan periodontal 10 kali lipat dibanding wanita dengan IMT normal. Wanita dengan lingkar pinggang normal mengalami kehilangan perlekatan periodontal $0,6 \mathrm{~mm}$ sedangkan wanita obesitas $1,9 \mathrm{~mm}$. Dalam indikator indeks gingival, wanita dengan IMT normal dan obesitas memiliki nilai indeks 0,3 dan 1,8. Wanita dengan lingkar pinggang normal dan obesitas memiliki nilai GI 0,5 dan 1,5. Pada laki-laki, nilai GI 0,4 dan 0,8 pada individu lingkar pinggang normal dan obesitas. Laki-laki dengan IMT normal mengalami kehilangan perlekatan $0,2 \mathrm{~mm}$ dan laki-laki obesitas $0,3 \mathrm{~mm}$. Hasil penelitian antara obesitas pada wanita dan laki-laki dengan CPI juga menujukkan korelasi positif yang signifikan ${ }^{10}$.

Gorman dan kolega menyatakan tiap peningkatan 1 IMT setara peningkatan 5 persen resiko kerusakan tulang alveolar. Setiap peningkatan $1 \mathrm{~cm}$ lingkar pinggang setara dengan peningkatan 1-2 persen penambahan kedalaman probing dan peningkatan resiko kehilangan perlekatan periodontal. Setiap kenaikan 1 persen rasio lingkar pinggang dan pinggul setara dengan peningkatan 3 persen resiko penyakit periodontal ${ }^{11}$.

\section{Mekanisme biologis hubungan obesitas terhadap periodontitis}

Mekanisme biologis peranan obesitas sebagai faktor resiko periodontitis diyakini diperankan utama oleh berbagai sitokin dan hormon yang merupakan turunan dari jaringan adiposa. Jaringan adiposa merupakan kompleks organ endokrin aktif yang mensekresi berbagai faktor imunomodulator yang berperan penting dalam mengatur metabolisme dan biologi vaskular ${ }^{12}$. Jaringan adiposa mengandung beberapa sel seperti 
fibroblast, preadiposit, adiposit dan makrofag. Sel adiposit, preadiposit dan makrofag mensekresi lebih dari 50 molekul aktif yang dikenal sebagai adipokin ${ }^{5}$.

Adipokin merupakan protein larut yang berikatan pada reseptor sel target dan menginisiasi sinyal antar selyang menghasilkan perubahan fenotip melalui perubahan ekspresi dan regulasi gen. Beberapa adipokin berperan lokal dan sebagian lainnya bekerja pada sirkulasi sistemik sebagai molekul aktif pada liver, otot, dan endothelium ${ }^{12}$.

Leptin merupakan polipeptida 16-kDa yang berperan ganda sebagai adipokin dan hormon. Leptin diproduksi utama oleh adiposit dan dalam jumlah sedikit juga diproduksi oleh plasenta, sel T, osteoblas dan epitel lambung ${ }^{5}$. Leptin berfungsi untuk menekan nafsu makan. Penelitian menunjukkan leptin berperan meningkatkan mekanisme imun melalui aktivasi fungsi monosit dan makrofag serta mengatur peran fagositosis, produksi sitokin, kemotaksis, dan produksi spesies oksidatif melalui stimulasi neutrofil, sel NK, dan meningkatkan respon sel T. Leptin juga menginduksi sekresi dan ekspresi IL-1ra oleh monosit. Reseptor pada leptin mampu menginduksi kelompok IL-6 yang merupakan mediator penting sebagai mediator keradangan pada fase akut. Peran leptin dalam homeostasis tulang dijalankan melalui dua peran yaitu memproduksi mediator untuk menstimulasi pembentukan tulang dan memperpanjang waktu aktif dari osteoblas, serta berperan negatif supresi metabolisme tulang melalui pengaturan hypothalamus ${ }^{12}$.

Adiponektin merupakan produk adiposit yang jumlahnya menurun pada individu obesitas. Adiponektin berperan positif pada jaringan periodontal dengan sifat anti keradangan dan efek antidiabetes dengan mencegah resistensi insulin. Efek positif ini didapat melalui perannya dalam menekan pembentukan dan aktivitas dari TNF- $\alpha$ dan IL-6 dan menginduksi produksi IL-1ra ${ }^{12}$.

TNF- $\alpha$ pada individu obesitas diproduksi utama oleh makrofag. Dalam kondisi obesitas jumlah makrofag dalam jaringan adiposa meningkat dari 5-10 persen menjadi 60 persen 5. Kemampuan TNF- $\alpha$ dalam meningkatkan jumlahnya secara cepat melalui mekanisme amplifikasi, serta peranannya yang sinergi dengan IL-1 menyebabkan peran TNF- $\alpha$ dalam timbulnya periodontitis sangat utama. TNF- $\alpha$ merupakan stimulan untuk proliferasi, aktivasi dan diferensiasi dari osteoklas, menginduksi produksi MMP oleh sel mesenkimal, stimulasi sel endotel untuk mengekspresikan selektin untuk merekrut leukosit, aktifasi makrofag untuk memproduksi IL-1 dan menginduksi pembentukan PGE2 oleh makrofag dan fibroblast ${ }^{13}$. Pada pasien obesitas, TNF- $\alpha$ juga menjadi inhibitor utama bagi adiponektin yang merupakan adipokin anti keradangan ${ }^{5,12}$.

Adipokin lain turut berperan dalam menyebabkan kerusakan jaringan periodontal melalui mekanisme resistensi insulin yang menyebabkan diabetes tipe 2. Adipokin yang berperan melalui mekanisme ini yaitu resistin, Interleukin-6 (IL-6), plasminogen activator inhibitor-1, angiotensinogen, C- reactive protein, chemerin, omentin dan apelin ${ }^{5}$.

\section{Mekanisme biologis hubungan periodontitis terhadap obesitas}

Kondisi rongga mulut yang tidak sehat secara tidak langsung berkontribusi terhadap timbulnya obesitas. Penyakit infeksi pada rongga mulut seperti karies, kelainan 
periapikal, gingivitis dan periodontitis menyebabkan gangguan kemampuan untuk mengunyah, sehingga kemungkinan untuk mengunyah makanan berserat dan bernutrisi tergantikan oleh makanan yang lebih lembut yang mengandung karbohidrat dan asam lemak jenuh sehingga memicu obesitas ${ }^{7}$.

Konsep Infectobesity yang diperkenalkan oleh Dr Nikhil membuka kemungkinan peran bakteri periodontal dalam menyebabkan obesitas. Infectobesity merupakan obesitas yang dipicu oleh adanya agen infeksius.5 Rongga mulut merupakan habitat bagi lebih dari 700 spesies bakteri. Socransky dan Haffajee memperkirakan sekitar 1 gram (1011) bakteri tertelan dalam 500-1500 $\mathrm{mL}$ saliva setiap harinya. 6 Spesies dari 4 filum bakteri jumlahnya meningkat pada individu obesitas yaitu Selenomonas noxia, Actinomyces gerencseriae, Actinomyces naeslundii, Neisseria mucosa, Fusobacterium periodonticum, Fusobacterium nucleatum, dan Prevotella melaninogenica ${ }^{14}$.

Penelitian Goodson menunjukkan $S$. noxia teridentifikasi pada 98,4 persen pada perempuan dengan berat badan berlebih dan obesitas. Meski penilitian tidak menunjukkan secara langsung peranan $S$. noxia terhadap obesitas, namun dengan persentase yang tinggi, maka bakteri ini dapat menjadi kandidat untuk dapat berperan langsung dalam obesitas. Jumlah bakteri ini meningkat dari 0,9 persen pada plak menjadi 5.9 persen pada daerah kerusakan periodontal. Periodontitis merupakan penyakit inflamasi yang disebabkan oleh bakteri kelompok merah seperti $P$. gingivalis, $T$. denticola dan $T$. forsythia. Maka peranan bakteri tersebut tentu tidak dapat di kesampingkan dalam kaitannya dengan obesitas ${ }^{6}$.
Mekanisme periodontitis dalam memicu obesitas dapat diperankan oleh tingginya tingkat sitokin proinflamasi yang terdapat dalam sirkulasi pada kedua penyakit kronis tersebut. Menurut Genco, hal ini disebut dengan "systemic inflammatory overload". Produksi berbagai sitokin oleh jaringan adiposa pada individu obesitas, serta berbagai sitokin yang diinduksi oleh bakteri dan toksin dalam periodontitis menjadi area tumpang tindih yang menjadi ikatan antar kondisi ${ }^{9}$.

Goodson dan kolega mengajukan 3 mekanisme tentang peran bakteri rongga mulut terhadap obesitas. Mekanisme pertama adalah bakteri rongga mulut berkontribusi dalam peningkatan efisiensi penyimpanan lemak atau efisiensi metabolisme. Melalui mekanisme ini, meski individu mengkonsumsi sedikit kalori berlebih, menyebabkan peningkatan berat badan. Peningkatan konsumsi kalori 100kal/ hari dapat menyebabkan peningkatan berat badan $10 \mathrm{lbs} /$ tahun. Mekanisme kedua adalah melalui kontrol hormon leptin dan ghrelin yang mengatur nafsu makan dan rasa lapar. Pada individu dengan periodontitis dan obesitas memiliki kadar serum leptin tinggi yang dapat menyebabkan resistensi tubuh terhadap leptin, sehingga tidak dapat menekan nafsu makan dan dengan peningkatan rasa lapar oleh ghrelin akan meningkatkan konsumsi makanan berlebih. Mekanisme ketiga melalui peningkatan sitokin inflamasi seperti TNF- $\alpha$ dan penurunan aktivitas adiponektin. Mekanisme ini menyebabkan resistensi insulin yang memicu peningkatan penimbunan energi dalam bentuk lemak dibanding glikogen ${ }^{6}$. 


\section{Peran dokter gigi dalam penanganan periodontitis dan obesitas}

Obesitas berperan erat terhadap munculnya masalah kesehatan rongga mulut. Oleh karena itu dokter gigi harus dapat mengenali tanda dan gejala dari penyakit yang ditimbulkan oleh obesitas. Dengan mengetahui tanda dan gejala tersebut, maka dokter gigi dapat memberikan edukasi pada pasien untuk dapat mengontrol berat badan atau melalui rujukan kepada dokter umum dan ahli gizi untuk dapat meregulasi berat badan dari pasien ${ }^{15}$. Tendon dan kolega membuktikan bahwa perawatan periodontal yang dilakukan oleh dokter gigi memiliki korelasi positif terhadap profil lemak pasien ${ }^{16}$. Dengan peranan dokter gigi dalam mengatasi obesitas dan penyakit periodontal, maka dokter gigi turut berperan aktif dalam mencegah timbulnya masalah sistemik lainnya seperti diabetes mellitus, penyakit kardiovaskular, penyakit pernafasan, dan gangguan kehamilan.

\section{KESIMPULAN}

Terdapat hubungan dua arah antara obesitas dan penyakit periodontal. Jumlah jaringan adiposa yang berlebih pada individu obesitas menyebabkan tingginya level adipokin pemicu keradangan. Bakteri dan toksin pada periodontitis memicu respon tubuh untuk meningkatkan sitokin keradangan. Tingginya level sitokin pemicu keradangan dapat memicu obesitas dan periodontitis dalam dua arah. Menjaga kesehatan rongga mulut penting bagi individu obesitas. Dokter gigi harus memainkan peranan penting melalui edukasi pada pasien serta kerjasama dengan dokter dan sejawat lain dibidang gizi.

\section{DAFTAR PUSTAKA}

1. Riset Kesehatan Dasar 2013. Badan Penelitian dan Pengembangan Kesehatan Departemen Kesehatan Republik Indonesia 2013: 223-227

2. Nandya, Maduratna E., Fitria E. Status kesehatan jaringan periodontal pada pasien diabetes mellitus tipe 2 dibandingkan dengan pasien non diabetes mellitus berdasarkan GPI. Diakses pada Journal. unair.ac.id 11 November 2015

3. Malathi, Selvam. Obesity and its Role in Periodontal Disease-A Review. International Journal of Scientific Research and Reviews 2013; 2(4): 126-135

4. Krejci Charlene B., Bissada Nabil F., Obesity and periodontitis: a link Academy of General Dentistry 2013: 60-63

5. Suresh Snophia, Mahendra Jaideep. Multifactorial Relationship of Obesity and Periodontal Disease. Dentis Journal of Clinical and Diagnostic Research 2014; 8(4): 1-3

6. Goodson, J. M., Groppo, D., Halem, S., \& Carpino, E. Is obesity an oral bacterial disease? J Dent Res 2009; 88(6): 519-523.

7. Sartika Ratu Ayu Dewi. Faktor risiko obesitas pada anak 5-15 tahun di Indonesia. Makara kesehatan 2011; 15(1): 37-43

8. Walis M., Kłosek S. The role of obesity in modifying the course of periodontal diseases. Progress in Health Sciences 2014; 4(1): 195-199

9. Genco RJ. The three-way street. In: Oral and Whole Body Health.New York, NY: Scientific American, Inc.; 2006:18-22

10. Amin H. El-Sayed. Relationship between overall and abdominal obesity and periodontal disease among young adults. EMHJ 2010; 16 (4): 429-433

11. Gorman A, Kaye E.K., Apovian C., Fung T.T., Nunn M., Garcia R.I. Overweight and Obesity Predict Time to Periodontal Disease Progression in Men. J Clin Periodontol 2012; 39(2): 107-114.

12. Lawande Sandeep A. Obesity and periodontal disease: A multidirectional relationship? Journal of pharmaceutical and biomedical sciences 2012; 25(25): 252-256.

13. Dumitrescu Alexandrina L., Tanaka Masashi. Particular Aspects of Periodontal Disease Pathogenesis. Dalam: A.L. Dumitrescu, Etiology and Pathogenesis of Periodontal Disease, SpringerVerlag Berlin Heidelberg 2010: 77-103

14. Nahhas, G. J. Periodontal Microorganisms, Obesity, Chronic Inflammation, and Type 1 Diabetes. Doctoral dissertation 2014. Diakses pada http:// scholarcommons.sc.edu/etd/2941 (11 November 2015)

15. Tirth A, Tandon V. Role of Obesity in Chronic 
Periodontal Diseases: A Systematic Review. International Journal of Scientific Study 2015; 2(10): 104-107

16. Tendon S., Dhingra M.S., Lamba A.K., Verma M., Munjal A., Faraz F. Effect of periodontal therapy on serum lipid levels. Indian J Med Specialities 2010; 1: 19-25 